\title{
THE FEUDAL DOMAIN \\ OF PALLARS JUSSÀ (C. 1175): \\ A RECORD OF OBLIGATIONS AND CUSTOM*
}

\section{Th. N. Bisson}

Among diverse records pertaining to the administration of fiefs in Catalonia in the later twelfth century is an undated memorial of tenures and obligations in the county of Pallars Jussà. This record has been neglected by historians of Pallars because it is not to be found in the archives of that region. Its ideal edjtor would have been Ignasi Puig i Ferreté and many scholars will share my sorrow that this promising young medievalist did not live to complete his work on the early history of Pallars. The record poses problems that he could best have solved - and some that I cannot solve - but its interest for the study of feudal custom in the twelfth century is so considerable that some attempt to explain it should no longer be defferred'. As it happens the

- Abreviations: $\mathrm{ACA}=$ Arxiu de la Corona d'Aragó; $E C=$ Gran enciclopèdia catalana, 16 vols. (Barcelona, 1970-83); FAC = Fiscal accounts of Catalonia under the early count-kings (1151-1213), ed. T.N. Bisson, 2 vols. (Berkeley-Los Angeles, 1984).

${ }^{1}$ The standard treatment of Pallars in the twelfth century remains that of Ferran VALLS TABERNER, "Els origens dels comtats de Pallars i Ribagorça", Estudis Universitaris Catalans, ix (1915-16), 1-101. Ignasi Puig had collected an important supplementary documentation. With the kind assistance of Dr. 
record is preserved among the pergamins Extrainventari of the Arxiu de la Corona d'Aragó (series Cancelleria), a series in which Professor Frederic Udina Martorell has taken such devoted and productive interest. Dr. Udina introduced me to the ACA some twenty years ago and he has aided my research in many ways. The present study is offered to him in token of my gratitude.

ACA Extrainventari 3411 is a strip of parchment inscribed in a large clear hand characteristic of the upland counties. It contains a record of allods, manses, castles, and fiefs together with the names of tenants and knights holding of the count of Pallars Jussà. Someone wanted to know what the count possessed in domains and strongholds administered directly or enfeoffed or pledged and who were his chief tenants. Who needed this information? When? And why? These questions alone will occupy me here and to the extent that I can deal at all with the last of them - why the record was made - a larger problem will be suggested that must be reserved for treatment elsewhere.

Who made the record is not easy to say. The entries are almost exclusively in impersonal language that conceals the author's identity. These entries refer to the "count" (which count?), to the king, and to great and lesser tenants. Only the first entry contains clues to the author's identity, and even these clues are ambiguous. It says that Eus is an allod pledged for 320 morabetins, «\& habeo potestatem de ipso kastro \& Guilelmus d'isla erat suus solidus homo comitis $\aleph^{2}$. The obvious possibility is that it is the count of Pallars himself who says (or is made to say) «I have power of the castle". This possibility is strengthened when we consider alternatives. The scribe cannot have been writing in the king's name, for the king military obligations in hoste regis; even in the first entry the tenant of Eus is described as solidus

Maria-Mercè Costa, I have attempted to learn whether Dr. Puig had studied the text edited here, but without result. For comparable records, see T.N. BISSON, "Feudalism in twelfth-century Catalonia», Structures féodales et féodalisme dans l'Occident méditerranéen ( $x$-xm siècles). Bilan et perspectives de recherches, Bibliothèque de l'École Française de Rome 44, Rome 1980, pp. 173-192, at 187-188.

${ }^{2}$ Further references to the appended record are not noted. 
homo comitis. The only other possibility is the tenant Galceran de Pinós, of whom something is said below; but he, too, is mentioned only in objective terms. The most likely interpretation is therefore that a scribe writing for the count of Pallars began the record in the count's voice before deciding to represent the tenures as objective realities in third-person language. And if that is so we may further conjecture that the count in question was Ramon VI (1174-1178) ${ }^{3}$. Again in the first entry the imperfect form erat (above at note 2) suggests (although the phrase is not conclusive to this effect) that the scribe began by thinking of a late count historically instead of objectively. But in any case the record can hardly be much later than the time of Ramon's death, for he was the last (male) count of Pallars Jussà. Nor can it be much earlier than about 1175 , for it was only then that the king's men, fresh from their resumption of Rosselló, began to take interest in Pallars Jussà. Galceran de Pinós III was obliged to recognize before the king's court in 1180 that he had lent money to Count Arnau Mir (1112-1174), for which Toló castle was pledged, and later to Ramon VI, for which half of the villa of Guils was pledged ${ }^{4}$. Now the pledge of Toló figures in the memorial of domain, but not that of Guils, a circumstance from which we may infer that the memorial dates from early in the tenure of Ramon VI. If we may accordingly place it about 1175 , we may suppose that its purpose was to establish the state of the feudal domain of Pallars Jussà at the accession of a new count following the very long reign of his father.

Such a purpose is consistent with the contents of the record. It lists some 32 places or tenures, some eighteen, named tenants, plus an indeterminate number of castellans and knights. Three general observations may be made about this information. First, it was not intended to cover the comital domain in its entirety.

${ }^{3}$ See VALls TABERnER, «Els orígens dels comtats», 61-63; Santiago SOBREQUÉs VIDAL, Els barons de Catalunya (Barcelona 1957), p. 35. These writers reckon Ramon as the fifth count of his line. I follow Armand de Fluvia in calling him Ramon VI, EC, xi (1978), 223; and VALLS TABERNER, «Origens», 63 , in placing his death in 1178 .

$4 F A C$, ii, no. 36 , cf. no. 38 . 
One has only to compare this memorial with the testaments of Arnau Mir of 1157 and 1171 to see that numerous tenures in the heartland of Pallars Jussà are not mentioned in the later record: for example, manses al Llordà, Mur, Isona, Basturs, and Durro. Nor is the difference simply that between manses and castles. The testaments mention castles that do not figure in the memorial, while the latter for its part refers to at least one manse or unfortified domains. Nevertheless, it would be generally correct to conclude that the memorial is a feudal record, not a fiscal one. It is concerned above all with the count's military resources, with his allies and his alliances.

This point suggests a second observation. Of the 32 toponyms listed, at least eight are locations in Cerdanya or Conflent, far to the east of Pallars Jussà. None of these places figures in the testaments of Arnau Mir; what is more, in the memorial these places are listed first, preceding the castles of Pallars Jussà, Ribagorça, and Aragon. This fact tends to confirm our attribution of the memorial, for we know from his testament, dated 4 September 1177, that Ramon VI had holdings in Cerdanya and Conflent ${ }^{6}$. It is clear that Ramon had developed this eastern honor on his own; nothing was said of it in his father's second testament, one purpose of which was to define his son's right to a succession that had been devised very differently in 1157 .

My third observation pertains to the structure that revealed by the memorial. It is a complicated structure that suggests a conception of feudal order in full gestation. The basic principle is that castles and domains are held by the count or by his «solid men». The term solidus homo may be translated as «vassal», or more exactly as «liege vassal»; but as elsewhere in Catalonia the term vassalus is not employed?. Tenures are spoken of as allods (alodium, alodia) or as fiefs (fevum), but these terms are not categorically exclusive. "Guils is a comital allod and Gui-

5 VALLS TABERNER, «Els origens dels comtats», 56-61.

6 Ibid., 62-63.

7 Bisson, «Feudalism», pp. 175-176. On the usage solidus, see also Paul Guilhiermoz, Essai sur l'origine de la noblesse en france au Moyen-Age, Paris 1902, pp. 320, 324-326. 
llem Ramon holds it in fief of the count of Pallars only for his lifetime». Other mentions confirm that feva are conditional, temporary, or revocable tenures, just as they had been in the tenth century. This does not mean that baronial tenures of the count were never hereditary; it only means that such tenures were not fiefs. Cavelleriae held of the count are mentioned (as such) at Uisset. "Solidity" could be defined collectively: the «knights of Ur are solidus of the count of Pallars for the honor they hold of him». The knights of Osséja hold of the count «in fief».

There is perhaps one other form of tenure to be noted: tenure by pledge. No fewer than eleven (or one-third) of the domains were pledged for loans when our memorial was written, loans of sums ranging from $140 \mathrm{~s}$, to $3500 \mathrm{~s}$. Now in at least one case -that of Castellons for 500 morabetins - the pledge was of many years' standing, for it figures already in the testament of $1157^{8}$. It is true that at that time Arnau Mir expressed the hope that the pledge would soon be redeemed. Yet in this case as in those of pledges held by Galceran de Pinós, it looks very much as if the commission of castles to trusted creditors may have been a useful means of securing administrative service without creating hereditary tenures.

There are signs that the custom of castles is more developed, and perhaps less flexible, in the central and Aragonese domains of Pallars. Ramon de Casserras is the count's solidus for Lascuarre and the demesne of Montannana, for which he owes the count two knights in the king's host, which he supplies at his own expense. The service of two knights figures also at Soso, Aguilar, Buil, Castigaleu, and the valley of Bardaixí; at Fantova the obligation is three knights; at Luzás, Ricla, Cabañas de Ebro, and Castro it is one knight. More nearly uniform is the obligation for five castellanies of the heartland of Pallars Jussà: at Montannana, Arén, Orrit, Castissent, and Talarn the castellans each owe two knights for service within Pallars and Ribagorça, and one for the (king's) host.

The customs of Pallars Jussà thus vary according to zone. In

8 VALLS TABERNER, «Els origens dels comtats $», 58$. 
Ramon VI's acquisitions to the northeast, the stress is on the «solid» fidelity of the count's tenants; there alone is mentioned the Catalonian custom of taking «power» of castles. The tenants include great barons, such as Galceran de Pinós and the viscount of Fenouillet, as well as local barons and knights of Cerdanaya and Conflent. These men, we may surmise, are not so much "administrative tenants» as allies of a count anxious to extend his influence in a prosperous zone whose exploitation the countking was content to leave to the Templars and other barons of tested fidelity ${ }^{9}$. Perhaps not accidentally the pledged domains mentioned in the memorial lay mostly in the eastern zone. In Aragon, on the other hand, Ramon was heir to his father's tenancies at Buil, Ricla, and Cabañas de Ebro in fidelity to the king. In these places and doubtless also in the castellanies of Ribagorça, with their baronial subtenants and quotas of knights, we may discern the influence of Aragonese tenurial custom. Finally, there is an internal zone in Pallars Jussà proper where the system of quotas appears to be Aragonese, but in which the military obligation to the count is confined to Pallars and Ribagorça.

Everywhere the count is lord and overlord. He is lord of men as well as of domains. In fact, he possesses men like lands: «the knights of Uisset are the count's", and in describing the Aragonese domain the memorial lists comended men almost interchangeably with tenures of castles. Everwhere, moreover, the king is overlord: "the knights of Uisset are the count's, salva fidelitate regis $)$, a custom of reserved fealty likewise attested in Urgell ${ }^{10}$. Military obligations in Pallars and Aragon are subordinated to the king's overriding right to service in an extra-regional host.

\section{$* * *$}

The memorial of c. 1175 is thus a customal as well as an account. It shows us how the last dynastic count of Pallars Jussà conceived of his feudal domain. It suggests a recent effort to

${ }^{9}$ FAC, i, 193-195; ii, nos. 53, 76.

${ }^{10} \mathrm{ACA}$, Cancelleria, pergamins Pere 1,42 . On the systematizing of feudal obligations, BISSON, «Feudalism», pp. 185-192. 
reorganize military tenures to the advantage of higher lords, an effort attested in other parts of Old Catalonia during the same years. And it bears marks of the wider vision of Count Arnau $\mathrm{Mir}$, in whose long reign were ignited the last flickering hopes of an alternative dynastic principality stretching from Rosselló to the Ebro.

\title{
APPENDIX
}

\author{
[c. 1175]
}

Memorial of the feudal domain and customs of the count of Pallars Jussà.

ACA, Cancelleria, pergamins Extrainventari 3411. Original, parchment. $435 \times 159 \mathrm{~mm}$. Dry-point lined; three lines at bottom blank. Dorse: (1) in[strumen]tum super feudis comitis tam ... (S. XII) b; (2) instrumentum super guibusclam feudis Comitis (S. XIII); (3) $\mathrm{n}<20>$

The scribe's capitalization and punctuation are mostly retained in this transcription. The annotation is limited to points on which comment, query, or citations are provided. For the identifications, see Index Nominum.

Elz est alodim \& est ${ }^{\mathrm{a}}$ in pignora per .ccc. $\mathrm{ti}$ x. morabetinos. \& habeo potestatem de ipso kastro /(1) \& Guillelmus d'isla erat suus solidus homo comitis. ${ }^{1}$ Sudanies est alodium comitis ${ }^{2}$ in pignora per IxX̉x morabetinos. Ipsum mansum de beders cum suis pertinenciis est / ${ }^{(3)}$ alodium comitis. et est in pignora per mille solidos in cauallos et in

a alodium \& est, added in superscript. ${ }^{b}$ Sic. " solidi, first written solidus, the final overstroke struck through. " duos, preceded by duos, struck through. ' de, preceded by $\mathrm{s}$, struck through. ${ }^{1}$ milites, added in superscript. ${ }^{8}$ sunt, added in superscript. The correction is incomplete: cf. line 44.

I This appears to be a retrospective allusion to Arnau Mir, count of Pallars Jussà (1112-1174).

${ }^{2}$ Here and hereafter the comes mentioned appears to be Ramon VI (1174-1178). 
mulos. et tenet eum $/^{(4)}$ in pignora gauceran. \& tolo ${ }^{3}$ est alodium comitis et gauceran tenet eum in $/^{(9)}$ pignora per mille solidos denariorum barchinonensium. \& guils ${ }^{4}$ est alodium comitis \& $/(6)$ tenet eum guilelm ramon per feuum comitis paliarensis tantum in uita sua. Uice co $/^{(7)}$ mes de fenolled ${ }^{5}$ est solidus paliarensium comitis per uice comitatum sancto Stepha /(8) no. ${ }^{6}$ Petrus de domenoua est solidus paliarensium comitis per ipsum honorem de $/^{(9)} \mathrm{de}^{\mathrm{b}}$ ipsa lagosa. Milites de ur sunt solidus paliarensium comitis per honorem que $/(10)$ tenent de eo. Milites d'olceia sunt comitis per feuum que tenent de eo. Petrus $/$ (ii) de prullans et filii arnalli de fulla sunt comitis solidi ${ }^{\circ}$. et gauceran tenet eos per $/{ }^{(12)}$ comitem. Tost est alodium comitis \& est in pignora per quingentos morabeti $/{ }^{(13)}$ nos. Ipsa guardia est in pignora per .c. mo. Bescarre est in pignora per sep /(14) tingentos solidos. Castellons 7 sunt in pignora per quingentos solidos. Ipsa dominicatura de $/^{(15)}$ concas est in pignora per .cc. solidos. Milites de uisset sunt comitis salua fideli ${ }^{(16)}$ tate regis. \& omnes dominicaturas regis sunt comitis et clauers. et omnia alodia pla /(17) na. et totum campum longum. ${ }^{8}$ berengarius de araneis tenet unam cauelleriam $/(18)$ per comitem in uisset \& tenet eam in pignora per $\mathrm{x} x$. mo. domina de castrelenas $/{ }^{(19)}$ tenet unam cauelleriam in uisset per comitem tantum in uita sua. Ipsi cla $/^{(20)}$ uerii comitis tenent alodia plana in uisset per .. $\mathcal{C} c$. solidos. campum longvm /(21) cum suis pertinenciis non est in pignora. Raimundus de Casserras solidus comitis $/(22)$ per alascorre et per

${ }^{3}$ Probably Talló (pr. Lleida, com. Baixa Cerdanya, p.j. la Seu d'Urgell, mun. Bellver). See $F A C$, ii, nos. 36, 38, 53, $76^{21}$; Els castells catalans, 6 vols. in 7 (Barcelona, Dalmau, 1967-80), iv, 732.

${ }^{4}$ Probably Guils de Cerdanya (pr. Girona, com. Cerdanya, p.j. Puigcerdà). See FAC, ii, nos. $53^{5}, 76^{15,88}$.

${ }^{5}$ Arnau III viscount of Fenouillet seems to have died in 1173. The impersonal reference here may reflect uncertainty about the succession, which in fact passed to a sister or a daughter; see Pere Ponsich in EC, vii (1974), 365-366.

${ }^{6}$ Saint-Estève de Pomers (dép. Pyr-Or., ar. and c. Prades). For this castle see Anny de Pous, "Tours et châteaux de la "Vall de Feu" du moyen et du bas Conflent», Conflent, no. 70 (1974), pp. 220-224, citing research of Pierre Ponsich.

7 Castellons, probably near Lliminiana (pr. Lleida, com. Pallars Jussà, p.j. Tremp). The castles are cited in Liber feudorum maior, ed. Francisco Miquel Rosell, 2 vols. (Barcelona, 1945-47), i, no. 55; Els castells catalans, vi ${ }^{2}, 1379$. ${ }^{8}$ Campu[s] longu[s] (near Montannana, Pallars Jussà?), not identified. Cf. Catalunya carolingia, ed. Ramon d'Abadal i Vinyals, 2 vols. in 4 parts (Barcelona, Institut d'Estudis Catalans, Memòries de la Secció HistòricoArqueològica, 1926-55), iii², no. 303 . 
ipso dominico de montaniana. \& debet dare duos milites /(23) comiti in hoste regis et comes non det ei cibum neque faciat emenda. Ber $/(24)$ nardus de beranui per sos et per agilar duos milites sine cibo et sine

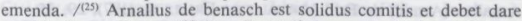
comiti .vii. cauallarios $/{ }^{(26)}$ sine cibo et sine emenda. De bardexi. duos milites sine cibo et sine emenda. $/^{(27)}$ De fontoa .iii. milites. unus roger. et unus. et unus castellanus. et unus guarinon. $/ /^{(28)} \&$ arnallus de erill habet mediatatem de ipso dominico quod comes habet ibi. De (29) boil duos ${ }^{d}$ milites sine cibo et sine emenda. De lozars. unum militem. ${ }^{(30)}$ sine cibo et sine emenda. sine hoc quod tenet roger et milites qui super eum sunt. ${ }^{(31)}$ Petrus de orreia duos milites. unum per ricla. et unem per cabanas. Petrus $/^{(32)}$ de cabanas unum militem. De castelgalef duos milites sine hoc quod haber $/{ }^{(33)}$ ibi petrus de girueta et gauzerandi. De kastre unum militem. sine hoc quod /(34) arnall de erill habet ibi. Ipsas dominicaturas de pregullana et ipsos clauers /35) \& excusatos de capela sunt comitis \& gonbal de siscar tenet per eum. Ipso /(36) castellano de montaniana debet dare duos milites ${ }^{t}$ inter paliars et ripacurcia /(37) $\&$ in hoste unum. Ipso castellano de areg duos milites debet dare intus $/{ }^{138}$ paliars et ripacurcia et unum in hoste. Ipso castellano de orrid debet dare /(39) duos milites intus paliars et ripacurcia. et unum in hoste. excepto hoc quod /(A0) seniores supra eos sunt ${ }^{8}$ habent supradictis castris. Ipso castellano de castelsancto /(41) duos milites debet dare intus paliars et riparcurcia et unum in hoste. Ipso /(42) castellano de talarn debet dare duos milites intus paliars et ripacurcia /(43) \& unum in hoste exceptis senioribus qui supra eos sunt in supradictis castris. /(44)

\section{INDEX NOMINUM}

This index refers only to the appended record. Numbers refer to lines. Modern forms are in SMALL CAPITAL LetTERs. The abbreviations are: ar. = arrondissement; $\mathrm{c} .=$ canton; ch.-I. = chef-lieu; com. = comar$c a$; dép. = département ;un. = municipi; $\mathrm{p} . \mathrm{j} .=$ partit $($ partida $)$ judi cial; pr. = provincia , Pyr-Or. $=$ Pyrénées-Orientales; vet. $=$ viscount.

Agilar (AGUILAR), 25.

Aguilar de Torruella de Aragón (Catalan. Aguilar de RibaGORÇA; pr. Huesca, p.j. Benabarre). See Agilar.

Alascorre (LASCUARRE), 23.

Araneis, see Berengarius de

Areg (ARÉN), castellanus de, 38. 
ARÉN (Catalan. Areny de Noguera, alta Ribagorça; pr. Huesca, p.j. Benabarre). See Areg.

Arnallus de Benasch, 26.

Arnallus (Arnall) de Erill (ARNAU I OF ERILL, d. 1197), 29, 35.

Arnallus de Fulla, sons of, 12.

ARNAU I of Erill, see Arnallus de Erill.

(ARNAU III, vct. of Fenouillet, d. 1173), cited 8.

Bardexi (VALLE DE BARDAJI), 27.

Beders (BEDERS: pr. Lleida, com. Baixa Cerdanya, p.j. la Seu d'Urgell), mansus of, 3 .

Benasch, see Arnallus de.

Beranui, see Bernardus de.

Berengarius de Araneis, 18.

Bernardus de Beranui, 24-25.

Bescarre (BISCARRI), 14.

BISCARRI (pr. Lleida, com. Pallars Jussà, p.j. Tremp, mun. Benavent de la Conca). See Bescarre.

Boil (BUIL), 30.

BuIL (Catalan. Boïl, Sobrarb; pr. Huesca, p.j. Boltaña). See Boil.

Cabanas (CABAÑAS DE EBRO: pr. Zaragoza, p.j. La Almunia de Doña Godina), 32. See also Petrus de Cabanas.

Campu[s] longu[s] (near MoNTANNANA?, not identified), 18, 21.

Casserras, see Raimundus de.

Castelgalef (CASTIGALEU), 33.

Castellons, probably near LLIMIANA, 15.

Castelsancto (CASTISSENT), castellanus de, 41.

CAS:IgAleu (Baixa Ribagorça; pr. Huesca, p.j. Benabarre). See Castelgalef.

CASTISSENT (pr. Lleida, com. Pallars Jussà, p.j. Tremp). See Castelgalef.

Castrelenas, domina de, 19.

CAstro (deserted, near La Puebla de Castro, pr. Huesca, p.j. Benabarre). See Kastre.

Concas (CONQUES), dominicatura de, 15-16.

CONQUES (pr. Lleida, com. Pallars Jussà, p.j. Tremp). See Concas.

Domenoua, see Petrus de.

Elz (EUS), 1.

Erill, see Arnallus de.

Eus (dép. Pyr-Or., ar. and c. Prades). See Elz

FANTOVA (Catalan. FonTOVA; pr. Huesca, p.j. Benabarre). See Fontoa.

Fenolled (FEnOUILLET: dép. Pyr-Or.), uice comes (ARNAU III) de, 7-8.

Fontoa (FANTOVA), 28.

Fulla, see Arnallus de.

GALCERÁN DE PINÓs, see Gauceran.

Gauceran, Gauzerandi (GALCERÁN III DE PINÓS, đ.c. 1196), 5, 8, $12,14$. 
Gauzerandi, see Gauceran.

Girueta, see Petrus de.

Gonbal de Siscar, 36.

GuARdiA DE NOGUERA, LA (pr. Lleida, com. Pallars Jussà, p.j.

Tremp), See ipsa Guardia.

Guarinon (proper name?), 28.

Guilelm Ramon, 7.

Guilelmus d'Isla, 2.

Guils (probably GUILS DE CERDANYA: pr. Girona, com. Cerdanya, p.j. Puigcerdà), 6 .

ipsa Guardia (LA GuẢrdiA dE NOGUERA), 14.

ipsa Lagosa (SAILlagousSE), 10.

Isla, see Guilelmus de.

Kastre (CASTRO), 34.

LASCUARRE (Catalan. LASQUARRI, Baixa Ribagorça; pr. Huesca, p.j.

Benabarre). See Alascorre.

LliminianA (pr. Lleida, com. Pallars Jussà, p.j. Tremp). See Castellons.

Lozars (LuzÁs), 30.

LuZÁs (pr. Huesca, p.j. Benabarre). See Lozars.

Montaniana (MONTANNANA), castellanus de, 37; dominicum de, 23. MONTANNANA (Catalan. MonTANYANA, Baixa Ribagorça; pr. Hues-

ca, p.j. Benabarre). See Campu[s] longu[s], Montaniana.

Olceia (OCEJA; French. OSSÉJA), 11.

Orreia, see Petrus de.

Orrid (ORRIT), castellanus de, 39.

ORRIT (pr. Lleida, com. Pallars Jussà, p.j. Tremp). See Orrid.

OsSÉJA (dép. Pyr.-Or., ar. Prades, c. Saillagousse-Llo). See Olceia.

Paliarensis-es, comes, 7, 10.

Paliars (PALlars), 37, 39, 40, 42, 43.

PALLARS, see Paliars.

Petrus de Cabanas, 32-33.

Petrus de Domenoua, 9.

Petrus de Girueta, 34.

Petrus de Orreia, 32.

Petrus de Prullans, 11-12.

Pregullana (not identified), dominicaturae de, 35.

Prullans, see Petrus de.

Ramon, see Guilelm Ramon.

Raimundus de Casserras, 22.

RiBAGORÇA, RIBAgORZA, see Ripacurcia.

Ricla (RICLA: pr. Zaragoza, p.j. La Almunia de Doña Godina), 32.

Ripacurcia (RIBAGorÇA, RIBAGORZA), 37, 39, 40, 42, 43.

Roger, 28, 31.

Saillagousse (dép. Pyr-Or., ar. Prades, ch.-1. c.). See ipsa Lagosa. 
SAINT-EstèVe De PoMers (dép. Pyr-Or., ar. and c. Prades), castle. See Sanctus Stephanus.

Sanctus Stephanus (SAINT-Estève DE POMERS), 8-9.

Siscar, see Gonbal de.

Sos (Soso), 25.

Soso (pr. Huesca, p.j. Benabarre). See Sos.

SOUANYAS (dép. Pyr-Or., ar. Prades, c. Olette). See Sudanies.

Sudanies (SOUANYAS), 2.

Talarn (TALARN: pr. Lleida, com. Pallars Jussà, p.j. Tremp), castellanus de, 43.

TALló (pr. Lleida, com. Baixa Cerdanya, p.j. la Seu d'Urgell, mun. Bellver). See Tolo.

Tolo (probably TALLO), 5.

Tost (TOST: pr. Lleida, com. Alt Urgell, p.j. la Seu d'Urgell), 13.

Ur (UrR: dép. Pyr-Or., ar. Prades, c. Saillagousse-Llo), 10.

VALLE DE BARDAJI (Catalan. BARDAIXi, Ribagorça; pr. Huesca, p.j. Boltaña). See Bardexi.

Uisset (Pallars Jussà, not identified), alodia in, 21; cauelleriae in, 18 20; dominicatura, milites de, 16. 